William R. Emmons is an economist at the Federal Reserve Bank of St. Louis. This article has been revised. The original published version contained an error regarding the tax treatment of adjustments to the principal of the Treasury inflation-indexed securities (TIIS).

\section{The Information Content of Treasury Inflation-Indexed Securities}

\section{William R. Emmons}

Econg conomists and monetary policymakers have long advocated government issuance of securities indexed to the price level - that is, inflationindexed bonds. Several theoretical considerations motivate this proposal. The government is wellsuited to bear large undiversifiable risks, such as future price-level uncertainty (inflation and deflation risk), so risk-sharing of this sort is likely to be welfare-enhancing as well as potentially profitable for the Treasury. Second, the existence of a large stock of government-issued inflation-indexed bonds should stiffen the resolve of the fiscal and monetary authorities to resist inflation, which most economists agree creates welfare losses to society. Third, prices generated at auctions or in secondary-market trading of inflation-indexed bonds should provide information about financial-market participants' expectations of real interest rates and inflation rates, which are important inputs into the monetary policymaking process.

This article first discusses the Fisher equation, which relates the ex ante, or expected, real interest rate and the expected inflation rate to the ex ante nominal interest rate. I then describe the mechanics of Treasury Inflation-Indexed Securities (TIIS ${ }^{1}$ ) and how they are traded. Finally, I describe the hypothetical components of the yields-to-maturity of TIIS and other fixed-income securities.

\section{EX ANTE REAL INTEREST RATES AND EXPECTED INFLATION}

Estimates of the ex ante real interest rate-the expected rate of increase in purchasing power a risk-free investment will deliver per time periodare essential for understanding and forecasting economic activity (Poole, 1999). Unfortunately, ex ante real interest rates are unobservable because the vast majority of financial contracts and prices are stated in nominal, or current-dollar, terms, rather than in units of constant purchasing power. Similarly, expected inflation is an important determinant of economic and financial activity that remains unobservable because no financial contracts written specifically on inflation currently trade in the United States.

\section{The Fisher Equation}

An early attempt to relate these two unobservable economic magnitudes to an observable quantity was made by Irving Fisher at the beginning of the last century. The so-called Fisher equation relates ex ante nominal and real interest rates to expected inflation in a simple framework:

$$
i_{t}=r_{t}+\pi_{t}^{e}
$$

where $i_{t}$ is the ex ante nominal interest rate observed at time $t, r_{t}$ is the ex ante real interest rate at $t$, and $\pi_{t}^{e}$ is the expected rate of inflation from $t$ forward, all for a given period of time, such as a year or ten years.

Various strategies for isolating the components of the Fisher equation have been proposed and tested. Before TIIS were available in the United States, estimates of the ex ante real interest rate often were obtained by rewriting the Fisher equation:

$$
r_{t}=i_{t}-\pi_{t}^{e}
$$

Many different nominal interest rates are available in financial markets. Expected inflation can be estimated by asking forecasters, businesses, or households their expectations, or by constructing models of the inflation rate. One such simple model is based on the persistence of inflation and can be estimated empirically:

$$
\pi_{t}^{e}=\beta \pi_{t-1}+\varepsilon_{t}
$$

\footnotetext{
1 TIIS sometimes are referred to as TIPS, which stands for Treasury Inflation-Protected Securities. The Treasury and the Federal Reserve typically use the TIIS acronym, so this article follows that convention.
} 


\section{Figure 1}

\section{Estimated Ex Ante Real 10-Year Treasury Yields}

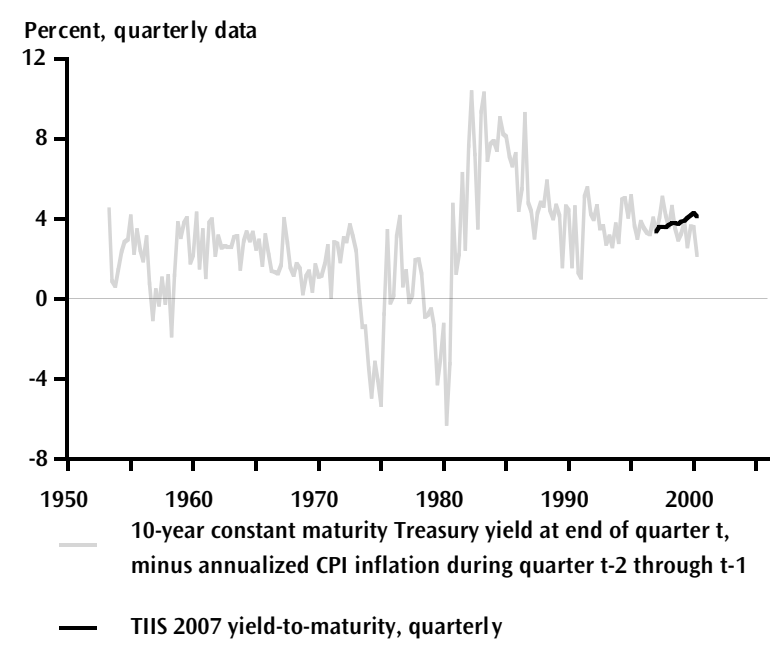

Figure 2

\section{TIIS Daily Yields-To-Maturity}

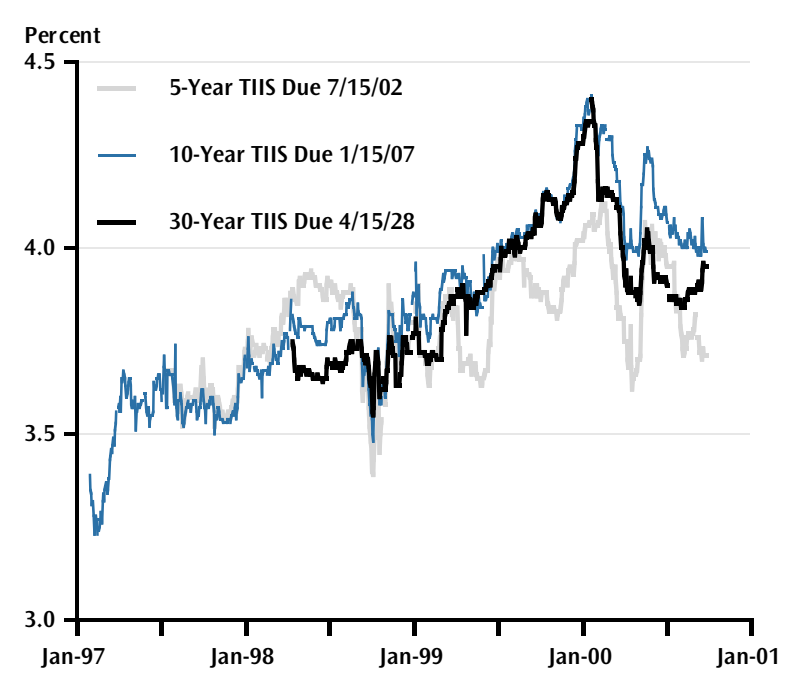

where $\pi_{t-1}$ is last period's inflation rate, $\beta$ is an estimated parameter (expected to be close to one), and $\varepsilon_{t}$ is the mean-zero forecast error. ${ }^{2}$ Figure 1 shows the result of an even simpler ex ante real interest-rate estimation procedure that sets $\beta$ equal to one and uses the end-of-quarter yield of a 10-year constant maturity nominal Treasury security as the ex ante nominal interest rate. ${ }^{3}$

It is interesting to note that the estimated ex ante 10-year real interest rate does not track the TIIS yield-to-maturity very closely, as Figure 1 indicates. Figure 2 shows that TIIS yields-to-maturity generally rose during 1997-99, before falling somewhat during 2000. Meanwhile, the estimated ex ante real rate derived from nominal Treasury yields and forecasted inflation fell more or less steadily. TIIS yields may have declined during early 2000 in part because investors apparently believed long-term Treasury securities of all types will be in short supply in the future as the Treasury's debt-repurchase plans are implemented.

As Figure 1 indicates, simple ad hoc methods of estimating ex ante real interest rates sometimes produce results that seem implausible. The exercise described above suggests that ex ante real interest rates may have ranged from negative 5 percent up to positive 10 percent in recent years. Fluctuations of this magnitude appear inconsistent with most theories of the long-term real interest rate. All indirect methods of estimating ex ante real interest rates are hampered by unobserved changes in market expectations or monetary-policy regimes that are not reflected immediately in the data. At the same time, Figure 2 indicates that TIIS yields-tomaturity are volatile, too, albeit in a smaller range.

Of course, we can rearrange the Fisher equation once more to obtain a simple model of expected inflation observable in real time if we are willing to accept the TIIS yield-to-maturity as a reasonable estimate of the ex ante real interest rate:

$$
\pi_{t}^{e}=i_{t}-r_{t}^{\text {TIIS }}
$$

where $r_{t}^{\text {TIIS }}$ is the yield-to-maturity of a TIIS.

\footnotetext{
2 Using quarterly data for the ten years ending in the second quarter of 2000 , the estimated $\beta$ is 0.93 , with a standard error of estimate of 0.06

${ }^{3}$ The estimated ex ante real interest rate is very similar if I use the oneyear constant-maturity Treasury yield.
} 
Figure 3 plots survey measures of 10-year inflation expectations against a simple TIIS-based estimate of expected inflation. The noticeable deviations between these two sources of long-term inflation forecasts raise questions about the reliability of either of these methods. Survey respondents may not answer candidly or carefully, while the information content of TIIS and other inflation-indexed securities around the world remains in doubt. ${ }^{4}$ The remaining sections of this article discuss several institutional and security-design features that may cause TIIS yields-to-maturity to deviate from the hypothetical concept of the ex ante real interest rate.

\section{UNITED STATES TREASURY INFLATION-INDEXED SECURITIES}

Treasury inflation-indexed securities were first issued in January 1997. As in other countries that have issued such securities, one of the U.S. Treasury's motivations was to reduce its cost of borrowing. Cost savings are possible if investors consistently demand a substantial inflation-risk premium in the yields of government securities that are denominated in nominal terms (i.e., conventional bills, notes, and bonds). By issuing securities whose real returns are protected against inflation, the Treasury avoids paying this risk premium. Of course, the government's interest expenses would go up if actual inflation turned out to be high, but it is reasonable to expect that government revenues also would rise due to incomplete inflation indexation of the tax code as well as from seigniorage earnings on outstanding currency and nominal debt. ${ }^{5}$ Thus, the government naturally is hedged against the risks incurred by issuing inflationindexed securities. However, there does not appear to be a substantial inflation-risk premium in the yields of nominal Treasury securities currently, so TIIS do not appear particularly "cheap" for the Treasury to issue today.

Original-issue maturities of TIIS thus far include 5,10 , and 30 years, although the Treasury recently has issued new securities only at the two longer maturities. The Treasury announced in early 2000 that only one 10-year and 30-year TIIS would be issued each year. As in the conventional Treasury security program, the intent is to focus issuing volume and secondary-market liquidity on a few benchmark securities.

\section{Figure 3}

\section{Estimates of Long-Term Inflation Expectations}

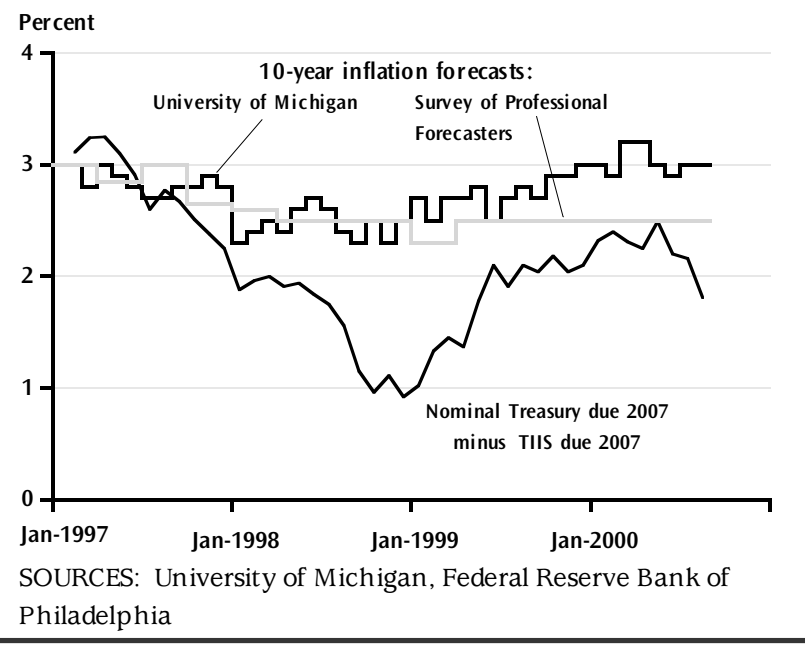

\section{What Are TIIS and How Do They Work?}

This section describes the cash flows paid and received by a buy-and-hold investor in an inflationindexed security. I also describe the tax liabilities such an investor incurs. An insert analyzes TIIS in terms of their hybrid nature - that is, the sense in which they appear to be part nominal bond and part a portfolio of call options written on the CPI.

Cash flows. A TIIS represents the Treasury's promise to make a periodic coupon payment at a fixed rate of interest applied to an inflation-adjusted principal, which is returned to the investor at maturity. The principal amount to be repaid is the greater of the initial principal or the principal adjusted for the cumulative percentage change in the CPI during the life of the security (United States Treasury, 2000a). In other words, the principal to be repaid at maturity

\footnotetext{
4 See Lashgari (2000) or Sack (2000) for recent analyses of TIIS

${ }^{5}$ Seigniorage refers to the transfer of real purchasing power to the issuer of nominal financial assets as a result of inflation. Monetary seigniorage results from the government's ability to issue currency that pays no interest when market interest rates are positive; investing the proceeds of currency issue in interest-bearing securities generates a profit. Economists sometimes also discuss bond seigniorage, which is the transfer of real purchasing power from investors to issuers when bonds lose real value as a result of unexpected increases in inflation and nominal interest rates.
} 


\section{Table 1}

\section{Cash Flows of a Tax-Exempt Buy-and-Hold Investor in TIIS}

\begin{tabular}{cccc} 
Date & Principal & $\begin{array}{c}\text { Interest payments } \\
\text { (Coupon rate: 4\%) }\end{array}$ & $\begin{array}{c}\text { Memo: } \\
\text { Level of CPI* }\end{array}$ \\
\hline January 15, 2000 & $-\$ 1000^{* * *}$ & & $\mathrm{P}_{0}$ \\
January 15, 2001 & & $+(0.04)\left(\mathrm{P}_{1} / \mathrm{P}_{0}\right)(1000)$ & $\mathrm{P}_{1}$ \\
January 15, 2002 & $+(0.04)\left(\mathrm{P}_{2} / \mathrm{P}_{0}\right)(1000)$ & $\mathrm{P}_{2}$ & $\mathrm{P}_{3}$ \\
January 15, 2003 & $+(0.04)\left(\mathrm{P}_{3} / \mathrm{P}_{0}\right)(1000)$ & $\mathrm{P}_{4}$ & $\mathrm{P}_{5}$ \\
January 15, 2004 & & $+(0.04)\left(\mathrm{P}_{4} / \mathrm{P}_{0}\right)(1000)$ & $\mathrm{P}_{6}$ \\
January 15, 2005 & & $+(0.04)\left(\mathrm{P}_{5} / \mathrm{P}_{0}\right)(1000)$ & $\mathrm{P}_{7}$ \\
January 15, 2006 & & $+(0.04)\left(\mathrm{P}_{6} / \mathrm{P}_{0}\right)(1000)$ & $\mathrm{P}_{8}$ \\
January 15, 2007 & & $+(0.04)\left(\mathrm{P}_{7} / \mathrm{P}_{0}\right)(1000)$ & $\mathrm{P}_{9}$ \\
January 15, 2008 & $+(0.04)\left(\mathrm{P}_{8} / \mathrm{P}_{0}\right)(1000)$ & $\mathrm{P}_{10}$
\end{tabular}

*I assume the CPI never falls below its level of January 15,2000 . That is, $\mathrm{P}_{0}$ is less than or equal to $\mathrm{P}_{t}$, for all $t=1$ to 10 . The text discusses the implications of a falling price level.

* * Negative signs indicate that the investor pays this amount and plus signs mean the investor receives this amount.

can be more, but never less, than its original amount.

Table 1 illustrates the cash flows a tax-exempt buy-and-hold investor in a 10-year TIIS with a 4percent coupon makes and receives during the life of the security. The level of the CPI in period zero - at the issue date-is written $P_{0}$, then $P_{1}$ at the end of the first year, and so on at the end of each year after issuance. ${ }^{6}$ For simplicity, I assume in Table 1 that the CPI never falls below its initial value, $P_{0}$. If it did-for example, if there was deflation during 2000 and $P_{1}<P_{0}$-the principal adjustment becomes more complicated, as discussed below.

Ongoing inflation adjustment of the principal value of the security is reflected in the dollar value of interest payments received each year. As shown in Table 1, a cumulative inflation-adjustment term containing the ratio of the then-current $\mathrm{CPI}$ level to the initial level of the CPI, $P_{t} / P_{0}$, causes interest payments to vary over time, even though the coupon rate remains fixed during the life of the security. At maturity, the inflation-adjusted principal is repaid. For convenience, this illustration assumes that all interest payments are made annually (in contrast to the actual practice of making semi-annual interest payments).

Table 2 provides an example of the actual cash flows that would be made and received by a taxexempt investor if the CPI increased by exactly 2 percent each year during the life of this security.
The annually compounded nominal rate of return on this investment is 6.08 percent, which reflects a 4-percent real rate of return, a 2-percent per year return to offset inflation, and a small compounding effect. In other words, if investors demanded no risk or illiquidity premiums in either nominal or indexed Treasury yields, an investor would have done just as well holding this 4-percent TIIS as a 10-year nominal Treasury security with a compounded annual yield-to-maturity of 6.08 percent.

Of course, the path of the CPI almost certainly will deviate from that which is expected, giving rise to differences in the realized returns on conventional and indexed securities. For example, a larger than expected increase in the CPI during the life of the security raises the nominal (that is, actual-dollar) return on the TIIS, while a conventional security's nominal return is fixed. In real (inflation-adjusted) terms, therefore, the TIIS return remains constant while that of the conventional security falls. The case of a smaller than expected increase in the CPI during the holding period creates the opposite pattern of relative returns. The boxed insert provides an alter-

\footnotetext{
${ }^{6}$ The CPI level is an index number with a base of 100 calibrated to a basket of goods and services in 1982-84. CPI inflation is the percentage change in the CPI level during a given period of time, usually expressed on an annualized basis.
} 


\section{Table 2}

\section{Hypothetical Cash Flows of a Tax-Exempt Buy-and-Hold Investor in TIIS}

\begin{tabular}{|c|c|c|c|}
\hline Date & Principal & $\begin{array}{l}\text { Interest payments } \\
\text { (Coupon rate: } 4 \% \text { ) }\end{array}$ & $\begin{array}{l}\text { Memo: } \\
\text { CPI level rebased to } 100 \\
\text { at January } 15,2000^{*}\end{array}$ \\
\hline January 15, 2000 & $-\$ 1000^{* * *}$ & & 100.00 \\
\hline January 15, 2001 & & $+\$ 40.80$ & 102.00 \\
\hline January 15, 2002 & & +41.62 & 104.04 \\
\hline January 15, 2003 & & +42.45 & 106.12 \\
\hline January 15, 2004 & & +43.30 & 108.24 \\
\hline January 15, 2005 & & +44.16 & 110.41 \\
\hline January 15, 2006 & & +45.05 & 112.62 \\
\hline January 15, 2007 & & +45.95 & 114.87 \\
\hline January 15, 2008 & & +46.87 & 117.17 \\
\hline January 15, 2009 & & +47.80 & 119.51 \\
\hline January 15, 2010 & +1219.00 & +48.76 & 121.90 \\
\hline
\end{tabular}

native interpretation of TIIS as hybrid securities.

Taxes. A taxable investor in TIIS faces two different types of tax liability every year, arising from interest income and capital gains. Table 3 describes how the tax liabilities of a buy-and-hold investor in the 28-percent marginal income-tax bracket are calculated, where capital gains are taxed at a 20percent rate. Table 4 applies these tax formulas to the example introduced above in which actual inflation turns out to be exactly 2 percent per year over the holding period.

The fact that ongoing inflation adjustments of the principal create a current capital-gains tax liability - even though a buy-and-hold investor receives no cash for the inflation adjustment before maturity - may decrease the attractiveness of TIIS for some investors. This tax treatment is consistent with that accorded zero-coupon and other original-issue discount bonds, however. Notice that the return of the original principal amount, $\$ 1,000$, is not taxable; only increases in the principal are taxed.

\section{Market Trading and Pricing of TIIS}

In principle, the market value of any security is the present discounted value of all the cash flows the security will provide in the future. Most people are accustomed to trading securities in nominal terms and quoting yields-to-maturity as nominal rates. A conventional bond's nominal cash flows are known in advance, so the nominal yield-to-maturity is calculated easily. The future real cash flows of a nominal bond-the purchasing power those nominal cash flows will provide - are not known today, however, because inflation cannot be predicted perfectly. The opposite is true of a TIIS: its future nominal cash flows are not known, but its inflation-adjusted cash flows are fixed. Thus, it is natural to quote the yieldto-maturity of a TIIS in real terms.

Consider the following example. The 4-percent coupon, 10-year TIIS illustrated in Tables 1-5 is issued by the Treasury on January 15, 2000, at 100 percent of par ("percent of par" is the market convention for quoting bond prices). In other words, a buyer is willing to pay 100 percent of the principal amount, which is $\$ 1,000$. Assuming that the investor expects annually compounded inflation of 2 percent per year during the life of the security, she would be indifferent between buying this TIIS and buying an equal-duration conventional Treasury security with a nominal yield-to-maturity of 6.08 percent. $^{7}$

\footnotetext{
${ }^{7}$ I assume the investor is risk-neutral, is tax-exempt, and may wish to sell the security before maturity. The last assumption implies that the investor is indifferent between buying a more liquid security, such as an on-the-run conventional Treasury, and buying a less-liquid off-therun Treasury, like a TIIS, whose yield includes an illiquidity premium.
} 


\section{TREASURY INFLATION-INDEXED SECURITIES AS HYBRID SECURITIES}

Another way to think about TIIS is to ask what one could add to a conventional Treasury security to generate payoffs identical to those of a TIIS. Like a conventional Treasury note or bond, a TIIS promises a fixed coupon rate of interest and guarantees the repayment of principal at maturity. If there were no inflation during the security's life, a TIIS would mirror a conventional security exactly. Differences in payoffs arise only if the price level changes.

For a conventional bond, the principal is fixed in dollar terms when issued; for a TIIS, the principal is restated periodically (in practice, every month) to reflect the evolution of the CPI. Interest payments rise if inflation occurs. Because this protects an investor against a loss in purchasing power of the principal invested, the initial required interest rate on such a bond can be lower than on a nonindexed security.

An interesting - and potentially valuable-feature of TIIS is their modified "upward-only" pricelevel adjustment clause. To be precise, the principal of a TIIS is increased by the percentage increase in the CPI or decreased by the percentage decrease in the CPI unless such adjustment would reduce the principal below its initial value. In this case, principal adjustments cease unless or until the CPI rises over its initial level at issuance $\left(P_{0}\right)$.

The perfectly flexible upward adjustment of principal in response to inflation and the truncated downward adjustment if prices fall below $P_{0}$ is reminiscent of a call option. A call option is a security that allows an investor to capture increases in the price of the asset on which it is written, while avoiding losses from a declining price (by allowing the option to expire unexercised). Indeed, a TIIS can be seen as a conventional nominal fixed-income security plus a portfolio of call options written on the CPI. This portfolio contains one call option for each cash flow promised by the TIIS; intuitively, this is necessary to provide full inflation protection over the life of the security. The strike price of all the options in the portfolio is the CPI level at issue, $P_{0}{ }^{1}$ All the options are "in-the-money" (i.e., valuable if exercised) whenever the current price level is above $P_{0}$ and they are "out-of-the-money" (not valuable if exercised) when the CPI level is below $P_{0}$.

Table 5 shows the payoffs of a 4-percent, 10year TIIS, rearranged to mimic a 4-percent nominal bond plus a portfolio of European call options (i.e., no early exercise permitted). ${ }^{2}$ One option corresponds to each of the security's cash flows. Notice that two options expire at the end of the security's life, corresponding to the last interest payment and the repayment of inflation-adjusted principal. It is easy to verify that Tables 1 and 5 describe identical payoffs to the investor by equating the sum of the middle two columns in Table 1 with the three columns of cash flows in Table 5. Thus, it is as if a TIIS investor received a fixed coupon rate of interest on a fixed nominal principal plus variable compensation in the form of call options written on the CPI for any cumulative inflation that occurs during the life of the security. ${ }^{3}$

${ }^{1}$ A call option's strike price is the amount the optionholder must pay to exercise the option.

${ }^{2}$ The notation "max $\left\{P_{t}, P_{0}\right\}$ " means that the greater of the current price level or the initial price level is used to value each option. Clearly, if $P_{t}<P_{0}$, then the time- $t$ option is worthless at $t$ and it expires unexercised. In this case, the investor receives only the cash payments in the two middle columns of Table 5. This asymmetric price-level adjustment feature provides a TIIS investor with some protection against deflation in addition to the complete inflation protection it offers.

${ }^{3}$ Two other, essentially equivalent, interpretations of TIIS are worth mentioning. Like a conventional Treasury bond but unlike a stock, a TIIS provides a guaranteed stream of income. On the other hand, like a stock but unlike a conventional Treasury bond, the purchasing power of the investor's principal may be protected against inflation. Thus, a TIIS can be seen as a hybrid security that provides some features of government bonds and some features of claims on real assets, like stocks. Another characterization of TIIS is as a substitute for an actively managed portfolio of long-term and short-term government securities (Kopcke and Kimball, 1999). In this interpretation, an investor can hold TIIS instead of a portfolio of long-term bondswhich typically provide higher coupon rates-and short-term securities-which can serve as a hedge against unexpected inflation. 


\section{Table 3}

Tax Liabilities of a Buy-and-Hold Investor in TIIS With 28-Percent Marginal Tax Rate on Ordinary Income

\begin{tabular}{|c|c|c|c|}
\hline Date & $\begin{array}{l}\text { Inflation-adustment } \\
\text { tax liability }\end{array}$ & $\begin{array}{l}\text { Interest-income } \\
\text { tax liability }\end{array}$ & $\begin{array}{c}\text { Memo: } \\
\text { Level of CPI* }\end{array}$ \\
\hline January 15, 2000 & & & $\mathrm{P}_{0}$ \\
\hline January 15, 2001 & $0.28 \times \frac{P_{1}-P_{0}}{P_{0}} \times \$ 1000$ & $0.28 \times 0.04 \times \frac{P_{1}}{P_{0}} \times \$ 1000$ & $\mathrm{P}_{1}$ \\
\hline January 15, 2002 & $0.28 \times \frac{P_{2}-P_{1}}{P_{1}} \times 1000$ & $0.28 \times 0.04 \times \frac{P_{2}}{P_{0}} \times 1000$ & $\mathrm{P}_{2}$ \\
\hline January 15, 2003 & $0.28 \times \frac{P_{3}-P_{2}}{P_{2}} \times 1000$ & $0.28 \times 0.04 \times \frac{P_{3}}{P_{0}} \times 1000$ & $\mathrm{P}_{3}$ \\
\hline January 15, 2004 & $0.28 \times \frac{P_{4}-P_{3}}{P_{3}} \times 1000$ & $0.28 \times 0.04 \times \frac{P_{4}}{P_{0}} \times 1000$ & $\mathrm{P}_{4}$ \\
\hline January 15, 2005 & $0.28 \times \frac{P_{5}-P_{4}}{P_{4}} \times 1000$ & $0.28 \times 0.04 \times \frac{P_{5}}{P_{0}} \times 1000$ & $P_{5}$ \\
\hline January 15, 2006 & $0.28 \times \frac{P_{6}-P_{5}}{P_{5}} \times 1000$ & $0.28 \times 0.04 \times \frac{P_{6}}{P_{0}} \times 1000$ & $\mathrm{P}_{6}$ \\
\hline January 15, 2007 & $0.28 \times \frac{P_{7}-P_{6}}{P_{6}} \times 1000$ & $0.28 \times 0.04 \times \frac{P_{7}}{P_{0}} \times 1000$ & $\mathrm{P}_{7}$ \\
\hline January 15, 2008 & $0.28 \times \frac{P_{8}-P_{7}}{P_{7}} \times 1000$ & $0.28 \times 0.04 \times \frac{P_{8}}{P_{0}} \times 1000$ & $\mathrm{P}_{8}$ \\
\hline January 15, 2009 & $0.28 \times \frac{P_{9}-P_{8}}{P_{8}} \times 1000$ & $0.28 \times 0.04 \times \frac{P_{9}}{P_{0}} \times 1000$ & $\mathrm{P}_{9}$ \\
\hline January 15, 2010 & $0.28 \times \frac{P_{10}-P_{9}}{P_{9}} \times 1000$ & $0.28 \times 0.04 \times \frac{P_{10}}{P_{0}} \times 1000$ & $P_{10}$ \\
\hline
\end{tabular}

*I assume the CPI never falls below its level of January 15, 2000, that is, $P_{0}$ is less than or equal to $P_{t}$, t 51 to 10 .

Now suppose the investor wants to sell the TIIS on January 15, 2001 (after collecting the first coupon interest payment). What price will she receive? The notional dollar value of the investor's TIIS principal is 100 percent times the original principal, which is $\left(P_{1} / P_{0}\right) \times \$ 1,000 .^{8}$ If inflation was 2 percent over the past year (ignoring the 2-month indexation lag, which is discussed below), then $P_{1} / P_{0}=1.02$, and the principal of the security is $\$ 1,020$. The market price of this security depends on the market-determined yield-to-maturity, however, which changes every day.
Suppose the Treasury has just issued a new 9year TIIS (i.e., maturing in 2010) with a coupon of 4.50 percent. Assume that the auction price of this new security was 100 percent of par, or $\$ 1,000$. Ignoring bid-ask spreads and brokerage commissions,

\footnotetext{
${ }^{8}$ The principal's new value is "notional," i.e., hypothetical, because the Treasury will not buy back the security before maturity at this or any other price. This value is meaningful, however, because the notional principal value tracks the cumulative adjustments that determine cur rent inflation-adjustment tax liabilities and the security's redemption value at maturity.
} 


\section{Table 4}

\section{Hypothetical Tax Liabilities of a Taxable Buy-and-Hold Investor in TIIS}

\begin{tabular}{cccc} 
Date & $\begin{array}{c}\text { Inflation-adjustment } \\
\text { tax liability* }\end{array}$ & $\begin{array}{c}\text { Memo: } \\
\text { Interest-income } \\
\text { tax liability* }\end{array}$ & $\begin{array}{c}\text { CPI level rebased to 100 } \\
\text { at January 15, 2000** }\end{array}$ \\
\hline January 15, 2000 & $\$ 5.60$ & $\$ 11.42$ & 100.00 \\
January 15, 2001 & 5.60 & 11.65 & 102.00 \\
January 15, 2002 & 5.60 & 11.89 & 104.04 \\
January 15, 2003 & 5.60 & 12.12 & 106.12 \\
January 15, 2004 & 5.60 & 12.37 & 108.24 \\
January 15, 2005 & 5.60 & 12.61 & 110.41 \\
January 15, 2006 & 5.60 & 12.87 & 112.62 \\
January 15, 2007 & 5.60 & 13.12 & 114.87 \\
January 15, 2008 & 5.60 & 13.39 & 117.17 \\
January 15, 2009 & 5.60 & 13.65 & 119.51 \\
January 15, 2010 & & & 121.90
\end{tabular}

*4-percent coupon, 10-year TIIS with principal of $\$ 1,000$; ordinary-income tax rate of 28 percent.

* * I assume the CPI increases exactly two percent each year.

the investor's "old" TIIS must compete with the supply of "new" TIIS that have a higher coupon rate of interest. Clearly, the investor will not receive $\$ 1,020$ - the notional principal of her security-or even $\$ 1,000$ - the principal value of the new TIIS - for the "old" security with a lower coupon interest rate. How much less will she receive?

Bond-pricing calculations for a TIIS are analogous to those used for pricing conventional bonds. Each cash flow the security will deliver in the future -i.e., each interest payment and the return of the inflation-adjusted principal-is discounted to the present at the rate implied by a comparable security that sells at par. In other words, the 9-year TIIS with a 4.50-percent coupon selling at par provides the discount rate the buyer of the older TIIS will use to determine a fair price. Suppose market expectations are for a continuation of 2-percent annual inflation for at least the next nine years. As before, compounding effects raise the nominal yield-to-maturity slightly - this time, to 6.59 percent. Applying this discount rate to the older TIIS' expected cash flows, the price of the security turns out to be $\$ 982.93$. The market price of this TIIS is, therefore, about 96.4 percent of the principal (i.e., \$982.93/\$1020). The selling investor's one-year return from owning this security is $[(\$ 40.80+\$ 982.93) /(\$ 1000)]-1$, or 2.37 percent. The buyer of the old TIIS would expect to earn 4.50 percent per year-the real yield-tomaturity on the repriced security - plus the inflation rate during the remaining life of the security, 2 percent, plus a small compounding bonus. Notice that the TIIS selling at 96.4 percent of par will generate a larger capital gain than an original-issue security because redemption always occurs at 100 percent of the notional principal. Therefore, an investor's tax status may be a consideration in trades of this sort.

The case of a lower market-determined real yield-say, 3.50 percent-is analogous to the case described above and has opposite effects on the seller. In the simpler case in which the market's required yield-to-maturity does not change as time passes, the dollar proceeds of selling a TIIS can be found from the far right column of Table 2 by multiplying the rebased CPI by 10 .

\section{Market Size and Liquidity}

TIIS constitute a small fraction of the Treasury securities held by the public, but they represent a more significant fraction of the new securities that will be issued by the Treasury under current debt- 


\section{Table 5}

\section{Cash Flows From a Nominal Bond and a Portfolio of Call Options on the CPI}

\begin{tabular}{|c|c|c|c|}
\hline Date & $\begin{array}{c}\text { Principal of } \\
\text { nominal bond }\end{array}$ & $\begin{array}{l}\text { Interest payments } \\
\text { on nominal bond } \\
\text { (4-percent coupon) }\end{array}$ & $\begin{array}{l}\text { Exercise value of } \\
\text { expiring call options } \\
\text { written on the CPI }\end{array}$ \\
\hline January 15, 2000 & $-\$ 1000^{*}$ & & \\
\hline January 15, 2001 & & $+(0.04 \times \$ 1000)$ & $+\frac{\max \left\{P_{1}, P_{0}\right\}-P_{0}}{P_{0}} \times 0.04 \times \$ 1000$ \\
\hline January 15, 2002 & & $+(0.04 \times 1000)$ & $+\frac{\max \left\{P_{2}, P_{0}\right\}-P_{0}}{P_{0}} \times 0.04 \times 1000$ \\
\hline January 15, 2003 & & $+(0.04 \times 1000)$ & $+\frac{\max \left\{P_{3}, P_{0}\right\}-P_{0}}{P_{0}} \times 0.04 \times 1000$ \\
\hline January 15, 2004 & & $+(0.04 \times 1000)$ & $+\frac{\max \left\{P_{4}, P_{0}\right\}-P_{0}}{P_{0}} \times 0.04 \times 1000$ \\
\hline January 15, 2005 & & $+(0.04 \times 1000)$ & $+\frac{\max \left\{P_{5}, P_{0}\right\}-P_{0}}{P_{0}} \times 0.04 \times 1000$ \\
\hline January 15, 2006 & & $+(0.04 \times 1000)$ & $+\frac{\max \left\{P_{6}, P_{0}\right\}-P_{0}}{P_{0}} \times 0.04 \times 1000$ \\
\hline January 15, 2007 & & $+(0.04 \times 1000)$ & $+\frac{\max \left\{P_{7}, P_{0}\right\}-P_{0}}{P_{0}} \times 0.04 \times 1000$ \\
\hline January 15, 2008 & & $+(0.04 \times 1000)$ & $+\frac{\max \left\{P_{8}, P_{0}\right\}-P_{0}}{P_{0}} \times 0.04 \times 1000$ \\
\hline January 15, 2009 & & $+(0.04 \times 1000)$ & $+\frac{\max \left\{P_{9}, P_{0}\right\}-P_{0}}{P_{0}} \times 0.04 \times 1000$ \\
\hline January 15, 2010 & +1000 & $+(0.04 \times 1000)$ & $+\frac{\max \left\{P_{10}, P_{0}\right\}-P_{0}}{P_{0}} \times 1.04 \times 1000$ \\
\hline
\end{tabular}

*Negative signs indicate that the investor pays this amount and plus signs mean the investor receives this amount.

management plans. This implies that TIIS will constitute a growing fraction of outstanding publicly held Treasury debt in the future.

As of August 31,2000, TIIS outstanding amounted to almost $\$ 115$ billion (United States Treasury, 2000b; see Table 6). This represents only about 2 percent of the gross federal debt, $33 / 4$ percent of the marketable debt, and just over 5 percent of marketable Treasury notes and bonds. ${ }^{9}$ These ratios are increasing relatively rapidly, however, because: a) virtually all TIIS are many years from maturity, so none will be redeemed in the near future, $b$ ) inflation-indexed 10-year and 30-year securities currently constitute one third to one half of total new Treasury issuance at those maturities, c) net Treasury security issuance will remain negative for the foreseeable future, particularly for conventional notes and bonds as the Treasury's recently announced repurchase program is implemented, and d) inflation indexation of the principal of TIIS increases their notional principal

\footnotetext{
${ }^{9}$ For comparison, approximately 22 percent of British Government debt is linked to an inflation index.
} 
Table 6

Interest-Bearing Marketable Treasury Debt August 31, 2000

\begin{tabular}{lcc} 
& $\begin{array}{c}\text { Conventional (unindexed) } \\
\text { (\$ billions) }\end{array}$ & $\begin{array}{c}\text { Inflation - Indexed } \\
\text { (\$ billions) }\end{array}$ \\
\hline $\begin{array}{l}\text { Bills } \\
\text { (discount securities with original maturities of } 12 \text { months or less) }\end{array}$ & 647 & - \\
$\begin{array}{l}\text { Notes } \\
\text { (coupon securities with original maturities of } 2 \text { through 10 years) }\end{array}$ & 1,643 & 33 \\
$\begin{array}{l}\text { Bonds } \\
\text { (coupon securities with original maturities of more than 10 years) }\end{array}$ & 637 & \\
\multicolumn{1}{c}{ Total } & 2,927 & 115
\end{tabular}

SOURCE: U.S. Treasury (2000b).

amounts when the CPI increases.

Average daily TIIS turnover is about 1.7 percent of original-issue face value outstanding versus 5 percent of nominal issues (Dupont and Sack, 1999, p. 802). All TIIS are reported by dealers to trade as "off-the-run" securities. Off-the-run securities are less frequently traded and typically yield 5 to 20 basis points more than "on-the-run" securities. More evidence of illiquidity is that 7 of the 14 largest daily yield changes in the 10-year TIIS market had taken place around auction dates (ibid, p. 803). Finally, although daily yield changes in TIIS areunsurprisingly - not correlated highly with nominal yield changes, neither are they highly correlated across TIIS issues themselves, as Table 7 indicates. For example, the correlation of daily yield changes of the TIIS securities maturing in 2007 and 2028 is only about 0.46 . The comparable pair of conventional securities shows a daily yieldchange correlation of 0.91 . This suggests that a large fraction of daily price changes in the TIIS market are idiosyncratic, rather than being systematic or macroeconomic in nature.

Table 8 shows that TIIS yield changes are correlated much more highly among themselves at a monthly than at a daily frequency, as one would expect if common macroeconomic factors largely determine their prices and yields. For example, the TIIS maturing in 2007 and 2028 show a monthly yield-change correlation of 0.83 , not far below the comparable conventional Treasury pair's 0.90 correlation. Thus, it appears that TIIS yield changes may be meaningful at lower frequencies (monthly, quarterly, or annual), even if daily yield changes are very noisy. One must interpret TIIS yield levels and spreads cautiously, however, because they contain a variety of risk-related and institutionally driven yield premiums, as discussed below.

\section{COMPONENTS OF TIIS YIELDS}

TIIS yields are as close to the concept of ex ante real interest rates as are available in markets today, yet we know they depart from that ideal in several ways. A great deal of research has been done already to quantify some of the differences between theory and reality, but much remains to be learned.

\section{Distortions in TIIS Yields and TIIS-Based Indicators}

There are several likely differences between the level of TIIS yields and hypothetical ex ante real interest rates that complicate their use as financial indicators. The first two factors cited below should increase TIIS yields relative to the hypothetical default risk-free ex ante real interest rate, while the third and fourth factors can work in either direc- 


\section{Table 7}

\section{Correlations of Daily Yield Changes}

All available data, February 13, 1997-September 25, 2000

\begin{tabular}{|c|c|c|c|c|c|c|}
\hline & $\begin{array}{c}\text { TIIS } \\
\text { 5-year/2002 }\end{array}$ & $\begin{array}{c}\text { TIIS } \\
\text { 10-year/2007 }\end{array}$ & $\begin{array}{c}\text { TIIS } \\
\text { 30-year/2028 }\end{array}$ & $\begin{array}{c}\text { Nominal } \\
\text { 5-year/2002 }\end{array}$ & $\begin{array}{c}\text { Nominal } \\
\text { 10-year/2007 }\end{array}$ & $\begin{array}{c}\text { Nominal } \\
30 \text {-year/2028 }\end{array}$ \\
\hline TIIS 5/02 & 1.00 & 0.48 & 0.38 & 0.30 & 0.27 & 0.18 \\
\hline TIIS 10/07 & & 1.00 & 0.46 & 0.33 & 0.34 & 0.28 \\
\hline TIIS 30/28 & & & 1.00 & 0.20 & 0.21 & 0.20 \\
\hline Nom 5/02 & & & & 1.00 & 0.93 & 0.77 \\
\hline Nom 10/07 & & & & & 1.00 & 0.91 \\
\hline Nom 30/28 & & & & & & 1.00 \\
\hline
\end{tabular}

SOURCE: Haver Analytics (2000) and author's calculations.

tion, depending on the particular circumstances.

Imperfect indexation. TIIS expose investors to at least three forms of basis risk (that is, the possibility that the financial instrument is an imperfect hedge against the risk the investor faces). First, TIIS payoffs are pegged to the consumer price index, which is not a good proxy for the price level relevant to all investors (for example, a foreign investor). Second, the method of calculating the CPI in the future can be altered to the detriment of a TIIS investor. Third, there is a two-month lag between the public announcement of the CPI and the corresponding adjustment in the face value of TIIS (note: the lag is eight months in the United Kingdom). Thus, a TIIS investor is unprotected against inflation risk during the last two months of the security's life. All three forms of basis risk should cause TIIS yields to be higher than the hypothetical real interest rate, although reliable estimates of these yield premiums are not available.

Other risk and liquidity premiums. As noted above, the off-the-run illiquidity premium in TIIS is likely to be in the range of 5 to 20 basis points. The bid-ask spread in TIIS is likely to add up to another 5 basis points to a trader's costs (Dupont and Sack, 1999). Evans (1998) identifies a statistically significant and time-varying risk premium unique to British index-linked yields (versus conventional bonds) over the period 1983. 95 that averaged about 1.5 basis points. This risk premium is independent of any tax or basis-risk effects; it is essentially the price investors demand for giving up some desirable features of nominal government bonds such as high payoffs under deflation and smaller capital losses when real interest rates rise.

Note that the oft-discussed inflation-risk premium is a component of the nominal yield, not the TIIS yield. Empirical estimates of this premium in the United States and the United Kingdom range from zero to 150 basis points. Evidence from Britain (Evans, 1998) strongly rejects the hypothesis that this risk premium is zero, and the evidence also suggests that it is time-varying. Given the low and stable survey expectations of long-term U.S. inflation from today forward, it is plausible that the inflation-risk premium contained in current nominal Treasury yields is at the lower end of the estimated range.

Tax considerations. Normal increases in the face value of TIIS principal due to inflation indexation are taxable gains to investors, as described above. Hence, required yields should increase on TIIS whenever expected inflation rises and vice versa (Kopcke and Kimball, 1999). This creates a positive correlation between TIIS yields and expected inflationcontrary to the intuition of the Fisher equation, which postulates a zero correlation between the ex ante real rate and expected inflation. A positive correlation biases the spread between nominal and indexed securities - a measure of the inflation premium investors demand-toward zero, reducing its informativeness. This distortion is worse when inflation expectations are changing. It is probably very low now because survey measures of long-term inflation expectations are relatively stable. For example, the 10-year inflation forecast from the Survey of Professional Forecasters has remained in the 2.2 to 2.6 percent range for more than two years. 
Table 8

Correlations of Monthly Yield Changes

All available data, March 1997 -August 2000

\begin{tabular}{lcccccc} 
& $\begin{array}{c}\text { TIIS } \\
\text { 5-year/2002 }\end{array}$ & $\begin{array}{c}\text { TIIS } \\
\text { 10-year/2007 }\end{array}$ & $\begin{array}{c}\text { TIIS } \\
\text { 30-year/2028 }\end{array}$ & $\begin{array}{c}\text { Nominal } \\
\text { 5-year/2002 }\end{array}$ & $\begin{array}{c}\text { Nominal } \\
\text { 10-year/2007 }\end{array}$ & $\begin{array}{c}\text { Nominal } \\
\mathbf{3 0} \text {-year/2028 }\end{array}$ \\
\hline TIIS 5/02 & 1.00 & 0.84 & 0.54 & 0.55 & 0.56 & 0.59 \\
TIIS 10/07 & & 1.00 & 0.83 & 0.56 & 0.62 & 0.73 \\
TIIS 30/28 & & & 1.00 & 0.39 & 0.49 & 0.66 \\
Nom 5/02 & & & 1.00 & 0.97 & 0.81 \\
Nom 10/07 & & & & & 1.00 & 0.90 \\
Nom 30/28 & & & & & & 1.00
\end{tabular}

SOURCE: Haver Analytics (2000) and author's calculations.

Maturity vs. duration. The real values of cash flows from TIIS arrive later than those of nominal Treasury coupon securities of the same maturity, as shown above. Duration is the weighted average time to maturity of a security's cash flows and generally is considered a better summary statistic than maturity for describing an investor's exposure to interest rate and inflation risk. Later arrival of real cash flows means that TIIS durations are larger than those of nominal securities with identical maturities. ${ }^{10}$

\section{Comparison With Corporate and Conventional Treasury Yields}

Figure 4 presents a stylized breakdown of some of the major components in the yields of corporate and two types of Treasury bonds, nominal and indexed. These determinants of market yields include the following:

1. The real interest rate

2. Compensation for expected inflation

3. A default-risk premium

4. An illiquidity premium

5. Compensation for inflation risk

6. A premium for risks uniquely associated with TIIS

As the figure shows, corporate bond yields include components $1,2,3,4$, and 5 . An on-therun Treasury security yield includes components 1 , 2 , and 5. A TIIS includes components 1, 4, and 6 .
These very different yields-to-maturity co-exist in the market because they reflect different risks to investors and varying degrees of market liquidity. Markets price these securities to reflect investors' demands for different features. For example, an investor in any of these securities expects to earn a real return of 4 percent per year simply for giving up the use of her money today, apart from any other considerations that are priced separately. In addition to the yield components noted here, the TIIS investor may expect a gain arising from the security's inflation-adjustments, as well. In Figure 4, expected inflation is 2 percent per year and the inflation-risk premium - which TIIS investors do not receive because they do not bear inflation risk -is assumed to be 20 basis points.

For simplicity, duration is assumed to be identical for all three securities depicted in Figure 4. Taxes also are ignored because tax-exempt investors are likely to be price-setters in active markets; otherwise, they would earn arbitrage profits. The unique feature of a corporate bond's yield is the default-risk premium it contains, assumed here to be 1.5 percent per year. This yield premium, or credit spread, over a conventional Treasury security of the same maturity is about what an investor in a corporate bond with a AAA rating would receive today. Figure 4 assumes that both the corporate bond and the TIIS yields contain an illiquidity premium of 20 basis

\footnotetext{
${ }^{10}$ Nominal and indexed securities' durations are equal if the CPI is expected to remain constant.
} 
points, although, in practice, it may be larger for a corporate bond than for an off-the-run Treasury security like a TIIS. Finally, the TIIS yield contains a yield premium that compensates investors for the unique risks they face in holding such a security, as discussed above.

\section{CONCLUSIONS}

The United States Treasury's fledgling market for inflation-indexed securities holds out promise as a relatively reliable source of market information on ex ante real interest rates and, indirectly, expected inflation. Both of these quantities are important economic variables that heretofore have been difficult to estimate. Analytical techniques designed to extract estimates of real interest rates from TIIS yields-to-maturity must take into account several important institutional features, however. These include imperfect inflation indexation, risk and illiquidity premiums, tax considerations, and appropriate duration adjustments. Some attempts to carefully extract information about ex ante real interest rates and expected inflation have been made using British inflation-indexed securities (see Evans, 1998), but further research is needed.

Although day-to-day changes in TIIS yields-tomaturity appear to be influenced strongly by institutional and trading features of the market, monthto-month changes appear to be driven by macroeconomic factors. Thus, the TIIS market is likely to provide reasonable estimates of longer-term trends in ex ante real interest rates, even if the levels of TIIS yields-to-maturity may contain risk or illiquidity premiums that are time-varying and often too large to ignore. Similarly, simple TIIS-based indicators of expected inflation are probably too crude to provide reliable point estimates, but they may give valuable early warning signals of important changes in the market's forecast of inflation trends.

\section{REFERENCES}

Dupont, Dominique, and Brian Sack. "The Treasury Securities Market: Overview and Recent Developments," Federal Reserve Bulletin, vol. 85 (December 1999), pp. 785 806.

Evans, Martin D.D. "Real Rates, Expected Inflation, and Inflation Risk Premia," Journal of Finance, vol. 53 (February 1998), pp. 187-218.

\section{Figure 4}

\section{Components of Equal-Duration Corporate, Nominal Treasury, and TIIS Yields}

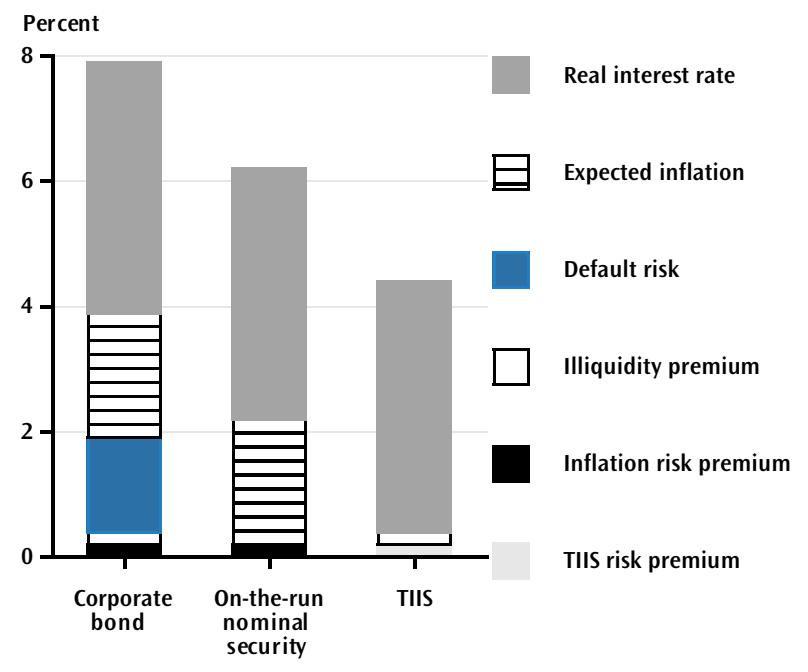

Kopcke, Richard W., and Ralph C. Kimball. "InflationIndexed Bonds: The Dog That Didn't Bark," New England Economic Review (January/February 1999), pp. 3-24.

Lashgari, Malek. "Information Content of U.S. Treasury Inflation-Indexed Bonds," International Advances in Economic Research, vol. 6, no. 3 (2000), pp. 520-30.

Poole, William. "Are Real Interest Rates Too High?” Speech given to the Money Marketeers of New York University, September 21, 1999, available at < http://www.stls.frb.org/ general/speeches/990921.html > .

Sack, Brian. "Deriving Inflation Expectations From Nominal and Inflation-Indexed Treasury Yields," Journal of Fixed Income, vol. 10, no. 2 (2000), pp. 6-17.

United States Treasury, Bureau of the Public Debt. "Summary of Marketable Treasury Inflation-Indexed Securities," January 31, 2000a, available at < http://www.publicdebt. treas.gov/gsr/gsrlist.htm >

United States Treasury, Bureau of the Public Debt. "Monthly Statement of the Public Debt Summary," August 31, 2000b, available at < http://www.publicdebt.treas.gov/opd/ opds082000.htm > 
RE V I E W

38 November/December 2000 